\title{
Marketing Fresh
}

Fruits and Vegetables 


\section{Marketing Fresh \\ Fruits and Vegetables}

\section{R. BRIAN HOW}

Cornell University

Springer Science+Business Media, LLC 
An AVI Book

(AVI is an imprint of Van Nostrand Reinhold)

Copyright(O1991 Springer Science+Business Media New York

Originally published by Van Nostrand Reinhold in 1991

Library of Congress Catalog Card Number 90-12952

ISBN 978-1-4613-5841-1

All rights reserved. No part of this work covered by the copyright hereon may be reproduced or used in any form or by any means-graphic, electronic, or mechanical, including photocopying, recording, taping, or information storage and retrieval systems-without written permission of the publisher.

\section{Library of Congress Cataloging-in-Publication Data}

How, R. Brian (Richard Brian)

Marketing fresh fruits and vegetables / R. Brian How.

p. $\mathrm{cm}$.

Includes bibliographical references and index.

ISBN 978-1-4613-5841-1 ISBN 978-1-4615-2031-3 (eBook)

DOI 10.1007/978-1-4615-2031-3

1. Fruits-Marketing. 2. Vegetables-Marketing. I. Title.

HD9240.5.H68 1990

$635^{\prime} .068^{\prime} 8-\mathrm{dc} 20 \quad 90-12952$

CIP 
To Janet, and to our children

Sarah, Katie, and George 


\section{Contents}

Preface / ix Acknowledgments / xiii

Part 1 Markets, Sources, and the Marketing System / 1

1. The United States Market for Food / 3

2. The United States Market for Fresh Fruits and Vegetables / 23

3. Sources of Fresh Fruits and Vegetables / 37

4. Major Sources of Supply: California, Florida, and Mexico / 53

5. The Marketing System and Firms Involved: An Overview / 74

6. Marketing Systems for Three Major Fruits and Vegetables: Oranges, Apples, and Tomatoes / 92

\section{Part 2 The Marketing Environment / 115}

7. Market Information: Agricultural Statistics, Grading and Inspection, Market News, and Other Information Sources / 117

8. Market Prices and Price Analysis / 129

9. Trade Practices, Credit Ratings, and Regulation of Trading (Perishable Agricultural Commodities Act) / 151

10. Cooperative Marketing / 163

11. Marketing Orders / 171

12. Pesticide Use and Food Safety / 179

13. Nutritional Quality and Nutrition Marketing / 204

14. Generic, Brand, and Private Label Advertising and Promotion / 217

Part 3 Marketing Operations and Firms / 229

15. International Trade / 231

16. Shipping Point Operations and Firms / 253 
viii CONTENTS

17. Long Distance Transportation / 266

18. Wholesaling at Destination and Terminal Market Facilities / 284

19. Food Retailers and Retailing / 301

20. The Foodservice Industry / 319

21. Direct Marketing by Farmers to Consumers / 328

Part 4 Epilogue / 341

22. Future Prospects / 343

Index / 349 


\section{Preface}

This book has evolved out of experience gained during 15 years of teaching a course on fruit and vegetable marketing to Cornell University undergraduates. Initially it was difficult to assemble written material that would introduce the students to the industry and provide examples to illustrate marketing principles. Apart from a few major studies like the U.S. Department of Agriculture's survey of wholesale markets that came out in 1964 or the report of the National Commission on Food Marketing published in 1966 there was little research to turn to in the early 1970s. Trade association meetings, trade papers, and personal contacts with members of the industry were the major sources of information. It became necessary to collect information from many different sources to fill the need for a descriptive base. Now there are many good research reports and articles being published on various phases of the industry. There still remains a pressing need, however, to consolidate and interpret this information so that it provides an understanding of the total system and its various parts.

Fresh fruit and vegetable marketing is different in many respects from the marketing of other agricultural and nonagricultural products. Hundreds of individual commodities comprise the total group. Each product has its own special requirements for growing and handling, with its own quality attributes, merchandising methods, and standards of consumer acceptance. However, many do share the general characteristics of being highly perishable and produced far from the market. Fruits and vegetables are marketed through many firms, some of which perform only a single function such as storage or transportation on a single commodity. Other firms, such as service wholesalers or retailers, handle a full line of fresh products. In an effort to preserve quality throughout the marketing system, these companies are increasingly using the latest technology in grading, storage, transportation, and merchandising. 
Recent advances in production technology are further influencing the manner in which fresh products are packaged, sold, shipped, and displayed at the retail level. Transactions between sellers at shipping points and buyers close to the market are generally made verbally with the product sight unseen. The informality with which these verbal agreements are made requires a high degree of confidence and trust. Trade terms and rules governing transactions are complex and specific to the produce industry.

The need for a text on this subject stems not only from the unusual nature of the business but also from the recent expansion in economic importance that has created new opportunities for existing firms and attracted the interest of other firms. The changes which are occurring in marketing practices, technology, and business organization point to the need for an even finer understanding of the industry and its peculiarities. American consumers' heightened interest in, and recent obsession with physical fitness, weight control, and the nutritional value of the foods we eat has greatly increased the total market for fresh fruits and vegetables, especially those that are unusual or exotic in nature. Over the past 20 years the volume of many individual commodities marketed in this country has increased several times, and total marketing charges for fresh fruits and vegetables has risen faster than for any other group of farm products. This added demand, along with improvements in transportation and the reduction in trade barriers has expanded the geographic area from which supplies are drawn. Large companies, some with nationally and internationally known brands of other foods, have been entering the business of marketing fresh products in increasing numbers. Existing firms have been fighting hard to maintain, if not increase, their share of the market.

The underlying approach taken in this book is that in order to evaluate the issues and alternatives, as well as the strengths and weaknesses, of the system it is first necessary to understand how each phase operates and how it has evolved. Only then is it possible to determine what factors will influence future directions and what the impact of various alternatives might be.

Logically this book is divided into four unequal parts. Part 1 provides an overview of the system by first considering the ultimate market for food and for fresh fruits and vegetables, the sources of supply in general and three major sources in particular, the total system that links sources and markets, and specific examples of the system for three products. After this introduction Part 2 describes the environment in which marketers must operate. This includes the study of information sources and communication networks, market prices, trade practices, farmer cooperatives, marketing orders, pesticide use, nutritional attributes, and advertising and promotion programs. Part 3 then looks at the marketing functions and firms involved in the actual process of moving these commodities through the system from 
international trade through shipping point, long distance transportation, destination wholesaling, retailing, foodservice, and direct marketing. Part 4 considers prospects for the future and the needs of the industry.

This book will provide members of the trade who are already involved in specific segments of the industry with a general background covering all phases of marketing from growing operations to retail merchandising, including past experiences, current developments, and emerging trends and issues that must be addressed by the private and public sectors. Those with experience in marketing other products who seek to enter the fresh fruit and vegetable arena will find this material a valuable resource in their attempts at better understanding produce practices and the forces that shape the business. The management of foreign businesses which are considering or are already marketing fresh fruits and vegetables in the United States will be able to gain greater knowledge of the fresh produce marketing system in this country. Many professionally trained workers at educational institutions who are employed on research or public educational programs to improve the growing, harvesting, and post-harvest handling of fresh fruits and vegetables will be guided by the additional knowledge of the economic aspects of the total marketing system. And the many public employees who estimate crop production, administer government regulations, report prices and product movement, and aid in policy development will more fully understand their role and their contribution to the total effort through the material contained in this book.

The objective of producing a book such as this goes far beyond simply providing a supplementary text for an undergraduate course or a reference for members of the industry. Ultimately it is hoped that a better understanding of the fresh produce marketing system and some knowledge of the structure and performance of the individual parts will contribute to better communication and coordination, improved service to the consumer, and greater distribution efficiency. It is further anticipated that the book will offer appropriate rewards to those members of the industry who wish to comprehend the issues, alternatives, and emerging trends and manage their operations accordingly. 


\section{Acknowledgments}

The attempt to describe and analyze such a complex and diverse industry as produce marketing is an ambitious project, and can only be accomplished with help from many different quarters. In a single chapter so many topics have to be covered, each one of which really requires specialized knowledge and deserves much fuller treatment. Any success in this task is due in large part to the help and encouragement provided from many willing sources.

I owe a great debt to the students who took the course over the years. Preparing to face a group of eager undergraduates two or three times a week for several months each year can be a real learning experience. Some had no previous knowledge of the subject, while for others produce marketing was born and bred in the bone, yet all contributed. Several have gone on to positions of responsibility in the industry, in government, or in academia, and my thanks go to them all.

The guest lecturers and field trip hosts were a great help in instructing me and my students, and in keeping me in touch with the real world. We were fortunate to visit, or have come to class, representatives from every phase of the industry and supporting public and private agencies. From them I learned about many aspects of the business that would otherwise have escaped my attention. I am reluctant to single out any for fear of offending others. However, I would like to mention two who came faithfully every year. Barney Mayrsohn kept us up to date on international trading, and Mel Nass reflected on his marketing experience including selling New York grapes to California buyers.

I have relied heavily on information from the U.S. Department of Agriculture. The Agricultural Marketing Service, the Foreign Agricultural Service, and the National Agricultural Statistical Service have provided a wealth of data. The Outlook and Situation reports and the food marketing 
analyses prepared by members of the Commodity Economics Division of the Economic Research Service have been invaluable sources, as citations in the text will testify. Their help is much appreciated.

At various stages in the project several of my colleagues at Cornell have reviewed chapters and made suggestions. I would particularly like to thank Bruce Anderson, David Blandford, Enrique Figueroa, Gene German, Bill Lesser, Ed McLaughlin, and Bill Tomek for their help. The manuscript has benefited greatly from their input, but they should not be held responsible for any remaining deficiencies.

Others who have helped include Wes Kriebel, Hal Linstrom, John Love, and Nancy Tucker. I owe a special debt to David Marguleas who, as a student, saw the potential for such a book, and more recently read a complete draft. I hope I have come close to living up to his expectations.

And finally, all members of my family have been remarkably supportive. Long ago when this endeavor was just a gleam in my eye they offered enthusiastic support. As it developed and came closer to fruition they continued to extend their encouragement, and have aided me in many ways. My wife, Janet, typed the first draft into the computer some time ago, and has recently provided editorial comment on the whole manuscript. In between she contributed in many ways, from relieving me of household chores to of fering suggestions on the general presentation. Each of the children has also helped in their own way, as has my son-in-law, Jim Alexander, and this has meant a great deal to me. 


\section{Marketing Fresh \\ Fruits and Vegetables}

